\title{
INCIDENCE AND POPULATION FLUCTUATION OF SPITTLEBUGS ON THREE PERENNIAL GRASSES: ON-FARM ASSESSMENTS
}

\author{
Leandro do Prado Ribeiro', Angélica Ribolli Cazarotto²
}

\begin{abstract}
Significant population outbreaks of spittlebugs (Hemiptera: Cercopidae) have been observed in perennial grasses (Poaceae) established in farms in South of Brazil. This situation is worrying local producers in relation to the continuous supply of forage due to the significant damage caused by this pest species complex. Thus, this study aimed to evaluate the incidence and populational fluctuation of spittlebugs (Hemiptera: Cercopidae) in three perennial grasses [Cynodon dactylon cv. Jiggs, C. dactylon cv. Tifton 85, and Axonopus catharinensis cv. SCS 315 Catarina Gigante (Poales: Poaceae)] in an experimental farm under semi-intensive milk production system. For this purpose, weekly counts of the foam produced by the spittlebugs nymphs were carried out in 10 points of $0.25 \mathrm{~m}^{2}(0.5 \times 0.5 \mathrm{~m})$ each, totalizing 35 assessments from the beginning of September 2015 to the end of April 2016. The incidence of spittlebugs was significantly different among the three perennial grasses. Lower incidence of spittlebugs was observed on A. catharinensis cv. SCS 315 Catarina Gigante (4.91 nymphs foam $\mathrm{m}^{-2}$ week $^{-1}$ in average), which is a natural species from South Brazil, followed by C. dactylon cv. Jiggs (6.51 nymphs foam $\mathrm{m}^{-2}$ week $^{-1}$ in average) and by C. dactylon cv. Tifton 85 (7.58 nymphs foam $\mathrm{m}^{-2}$ week $^{-1}$ in average). Moreover, three characteristic population peaks of spittlebugs was observed: the first in the end of September, the second in the middle of December, and the third in early February. However, the number of nymphs foam of spittlebugs was not significant correlated with the climatic parameters (precipitation, average temperature, and relative humidity) of periods (week) prior to the weekly sampling times. In light of these findings, A. catharinensis cv. SCS 315 Catarina Gigante constitutes an interesting option for establishing new pasture areas.
\end{abstract}

Keywords: Axonopus catharinensis, Cynodon spp., integrated management, varietal resistance.

\section{INCIDÊNCIA E FLUTUAÇÃO POPULACIONAL DE CIGARRINHAS-DAS- PASTAGENS EM TRÊS GRAMÍNEAS PERENES: AVALIAÇÕES EM CAMPO}

\begin{abstract}
RESUMO - Significativos surtos populacionais de cigarrinhas-das-pastagens (Hemiptera: Cercopidae) têm sido verificados em gramíneas perenes (Poaceae) estabelecidas em propriedades no sul do Brasil. Essa situação preocupa os produtores locais em relação ao contínuo fornecimento de forragem devido aos significativos danos causados por este complexo de espécies-praga. Assim, este estudo teve como objetivo avaliar a incidência e flutuação populacional de cigarrinhas-das-pastagens (Hemiptera: Cercopidae) em três gramíneas perenes [Cynodon dactylon cv. Jiggs, C. dactylon cv. Tifton 85 e Axonopus catharinensis cv. SCS 315 Catarina Gigante (Poales: Poaceae)] em uma propiedade sob sistema semi-intensivo de produção de leite. Para tanto, foram realizadas contagens semanais de espumas produzidas pelas ninfas em 10 pontos de $0,25 \mathrm{~m}^{2}(0,5 \times 0,5 \mathrm{~m})$ cada, totalizando 35 avaliações a partir do início de setembro de 2015 até o final de abril de 2016. A incidência de cigarrinhas foi significativamente diferente entre as três gramíneas perenes. A menor incidência de cigarrinhas foi observada em A. catharinensis cv. SCS 315 Catarina Gigante (4,91 ninfas de espuma m ${ }^{-2}$ semana $^{-1} \mathrm{em}^{-1}$ média), que é uma espécie natural do sul do Brasil, seguida por C. dactylon cv. Jiggs (6,51 espuma de ninfas $\mathrm{m}^{-2}$ semana $^{-1}$ em média) e por C. dactylon $\mathrm{cv}$. Tifton 85 (7,58 ninfas de espuma $\mathrm{m}^{-2}$ semana $^{-1}$ em média). Além disso, três picos populacionais característicos de cigarrinhas-das-pastagens foram observados: o primeiro
\end{abstract}

\footnotetext{
${ }^{1}$ Researcher, Research Center for Family Agriculture, Agricultural Research and Rural Extension Company of Santa Catarina (CEPAF/EPAGRI), Chapecó, Santa Catarina, Brazil, leandroribeiro@epagri.sc.gov.br.

${ }^{2}$ Agronomist, Federal University of the South Frontier (UFFS), Chapecó, Santa Catarina, Brazil, angelica.ribollicazarotto@gmail.com.
} 
no final de setembro, o segundo em meados de dezembro e o terceiro no início de fevereiro. No entanto, o número de ninfas não foi significativamente correlacionado com os parâmetros climáticos (precipitação, temperatura média e umidade relativa) dos períodos (semanas) anteriores aos tempos de amostragem. Diante desses resultados, A. catharinensis cv. SCS 315 Catarina Gigante constitui uma opção interessante para o estabelecimento de novas áreas de pastagem.

Palavras chave: Axonopus catharinensis, Cynodon spp., manejo integrado, resistência varietal.

\section{INTRODUCTION}

The land structure of South region of Brazil, majority composed by small farmers (Síntese Anual da Agricultura de Santa Catarina, 2014-2015), requires rising production rates of agricultural production systems in order to generate income in an amount necessary to ensure quality life and social reproducibility of the families allocated in rural areas. In light of this context and of importance of dairy farming for regional economy, it is necessary the constant generation of knowledge (and innovation) in order to solve the main technological limitations of the production chain, including the adequate phytosanitary management of pastures, which are the basis of milk production systems conducted in the region (Fernandes, 2012).

In the last years, significant population outbreaks of spittlebugs (Hemiptera: Cercopidae) have been observed in perennial grasses (Poaceae) established in farms in South of Brazil (Lohmann et al., 2010; Chiaradia et al., 2013). This situation is worrying local producers in relation to the continuous supply of forage along the year due to the significant damage caused by this pest species complex. The damage caused by spittlebugs are verified both in reducing the volume of dry matter produced forage (quantitative damage) and in reducing its nutritional quality (qualitative damage) (Valério \& Nakano, 1987; 1988; Congio et al., 2012), which are features that considerably limit the carrying capacity of pastures (Auad et al., 2007). Moreover, the intense attack of pests is one of the causes of pasturelands degradation, which is a chronic problem of Brazilian livestock production systems (Peron \& Evangelista, 2004).

The use of plant resistance constitutes a promising alternative for management of spittlebugs (Aguirre et al., 2013). Resistant genotypes can be used in an integrated management program along with other management strategies such as chemical and biological controls (Korndörfer et al., 2011; Grisoto et al., 2014). In Brazil, multi-institutional efforts have been made in order to obtain resistant genotypes; however, most of these research programs aims to select Brachiaria ecotypes (Urochloa sp.) adapted to conditions of extensive livestock farming practiced in the Midwest region of Brazil (Auad et al., 2007; Sobrino et al., 2010; Resende et al., 2012; 2013). In contrast, little is known about the behavior of the main perennial grasses utilized in semi-intensive milk production systems in South Brazil [Axonopus and Cynodon (Poaceae)] in relation to spittlebugs incidence as well as their ecological and behavioral aspects, especially under field conditions.

The present study aimed to evaluate the incidence and populational fluctuation of spittlebugs (Hemiptera: Cercopidae) in three perennial grasses [Cynodon dactylon cv. Jiggs, C. dactylon cv. Tifton 85, and Axonopus catharinensis cv. SCS 315 Catarina Gigante (Poales: Poaceae)] in an experimental farm under semiintensive milk production system.

\section{MATERIALAND METHODS}

\section{Study area}

This study was conducted in an experimental farm located in Chapecó, SC, Brazil ( $27^{\circ} 11^{\prime} 38.98^{\prime \prime} \mathrm{S} ; 52^{\circ}$ 39' 37.37" W, elevation: $645 \mathrm{~m}$ ) conducted under a semiintensive milk production system using a Voisin pasture rotational strategy. The samplings were carried out in three adjacent plots of $1800 \mathrm{~m}^{2}(60 \times 30 \mathrm{~m})$ cultivated with three perennial grasses [Cynodon dactylon $\mathrm{cv}$. Jiggs, C. dactylon cv. Tifton 85, and Axonopus catharinensis cv. SCS 315 Catarina Gigante (Poales: Poaceae)], which were established three years ago (summer of 2013).

The plots were located in a Rhodic Hapludox soil (Latossolo Vermelho distroférrico típico, in the Brazilian Soil Classification System) (Solos do Estado de Santa Catarina, 2004), and Cfb climate according to Köppen classification (Pandolfo et al., 2002). The experimental plots used in the assessments had similar declivity $(\sim 15 \%)$ and chemical and physical analysis showed 
that they had similar properties [means $\pm \mathrm{SE}(\%$ of clay $(\mathrm{w} / \mathrm{v})=60.67 \pm 0,76 ; \mathrm{pH}$-water $(1: 1)=5.68 \pm 0.04$; $\mathrm{P}\left(\mathrm{mg} \mathrm{dm}^{-3}\right)=24.88 \pm 1.83 ; \mathrm{K}\left(\mathrm{mg} \mathrm{dm}^{-3}\right)=190.28 \pm 20.24$; $\%$ of organic matter $\left(\mathrm{w} \mathrm{v}^{-1}\right)=3.45 \pm 0.03 ; \mathrm{Al}\left(\mathrm{cmolc} \mathrm{dm}^{-}\right.$ $\left.{ }^{3}\right)=0.014 \pm 0.014 ; \mathrm{Ca}\left(\mathrm{cmolc} \mathrm{dm}^{-3}\right)=5.56 \pm 0.19 ; \mathrm{Mg}(\mathrm{cmolc}$ $\left.\left.\left.\mathrm{dm}^{-3}\right)=2.37 \pm 0.08\right)\right]$.

During the assessments, the pasture was mowed two times (25/11/2015 and 11/02/2016) to remove herbage leftover. The fertilization in the plots was carried out before the start of the evaluations using pig slurry (doses equivalent to $100 \mathrm{~kg}$ of $\mathrm{N} /$ hectare).

\section{Spittlebugs population assessment and sampling}

Weekly counts of nymphs foam were carried out in 10 points of $0.25 \mathrm{~m}^{2}$ in each plot, totalizing 35 assessments from September 2015 to April 2016. For this purpose, we used an iron square $(0.5 \times 0.5 \mathrm{~m})$ that was randomly launched in 10 points of each area selected by means of a zig-zag displacement. On the other hand, adults of spittlebugs were sampled monthly by means of a sweep net (30 cm of diameter) in order to verify the predominant species in the plots.

The climate data (precipitation, average temperature, and relative humidity) were obtained with a meteorological station located at the assessed experimental area of Epagri/Cepaf (Chapecó, SC, Brazil) and they were correlated with number of spittlebugs in each plot. For this, we used the average values of climate parameters of the previous week that the nymphs foam assessment was performed.

\section{Data analysis}

Generalized linear model (GLM) (Nelder \& Wedderburn, 1972) with quasi-Poisson distributions was used for the analysis of nymphs foam count data. The goodness-of-fit was determined using a half-normal probability plot with a simulated envelope (Hinde \& Demétrio, 1998). When a significant difference was observed between the treatments, multiples comparisons (Tukey's post hoc test, $\mathrm{P}<0.05$ ) were performed using the glht function of the multicomp package with adjustment of $P$ values.

The relationship between the number of foams and climate data was determined using Spearman's nonparametric analysis $(\mathrm{P}=0.05)$. All analyses were performed using the software " $\mathrm{R}$ ", version 2.15.1 (R Development Core Team, 2012).

\section{RESULTS AND DISCUSSION}

The incidence of spittlebugs was significantly different among the three perennial grasses (GLM with quasi-Poisson distribution $=\mathrm{F}_{(2,27)}:$ 7.77; P: 0.0004) (Figure 1). Lower incidence of spittlebugs was observed on A. catharinensis cv. SCS 315 Catarina Gigante (4.91 nymphs foam $\mathrm{m}^{-2}$ week $^{-1}$ in average), which is a natural species from South Brazil, followed by C. dactylon cv. Jiggs (6.51 nymphs foam $\mathrm{m}^{-2}$ week $^{-1}$ in average) and by C. dactylon cv. Tifton 85 (7.58 nymphs foam $\mathrm{m}^{-2}$ week $^{-1}$ in average), which did not show significant difference between them. In hypothesis, the low incidence of spittlebugs (reduction variable between 32 and 54\%) in A. catharinensis cv. SCS 315 Catarina Gigante should be result of resistance of antixenosis and/or antibiosis type. However, the type of resistance taking place in A. catharinensis cv. SCS 315 Catarina Gigante to spittlebugs needs to be better investigated in further studies under controlled conditions. In light of these findings, A. catharinensis cv. SCS 315 Catarina Gigante constitutes an interesting option for establishing of new pasture areas.

The most abundant species collected in the plots was Notozulia entreriana (Berg, 1879) representing $73.7 \%$ of the total individuals collected $(n=1,536)$ during the sampling period, without, however, occur significant difference in the species proportion between the studied plots. Corroborating our findings, Lohmann et al. (2010) also verified the predominance of $N$. entreriana in pastures of bermudagrass (C. dactylon) and sedges (Rhynchospora sp.) in the western region of Paraná State, Brazil. On the other hand, Chiaradia et al. (2013) verified predominance of Deois flavopicta (Stal., 1854) and Deois schach (F., 1787) in giant missionary grass (A. catharinensis) in Chapecó, SC, Brazil, indicating a change in the species proportion over the years.

Three or four population peaks were verified during the critical period of incidence of spittlebugs in previous studies conducted in South Brazil (Lohmann et al., 2010; Chiaradia et al., 2013). In the present work, three characteristic population peaks of spittlebugs were observed (Figure 2): the first in the end of September, the second in the middle of December, and the third starting in early February. This result indicates that, in these periods, the monitoring of spittlebugs should be intensified in order to determine the appropriate time for adoption of insect pest control strategies. 


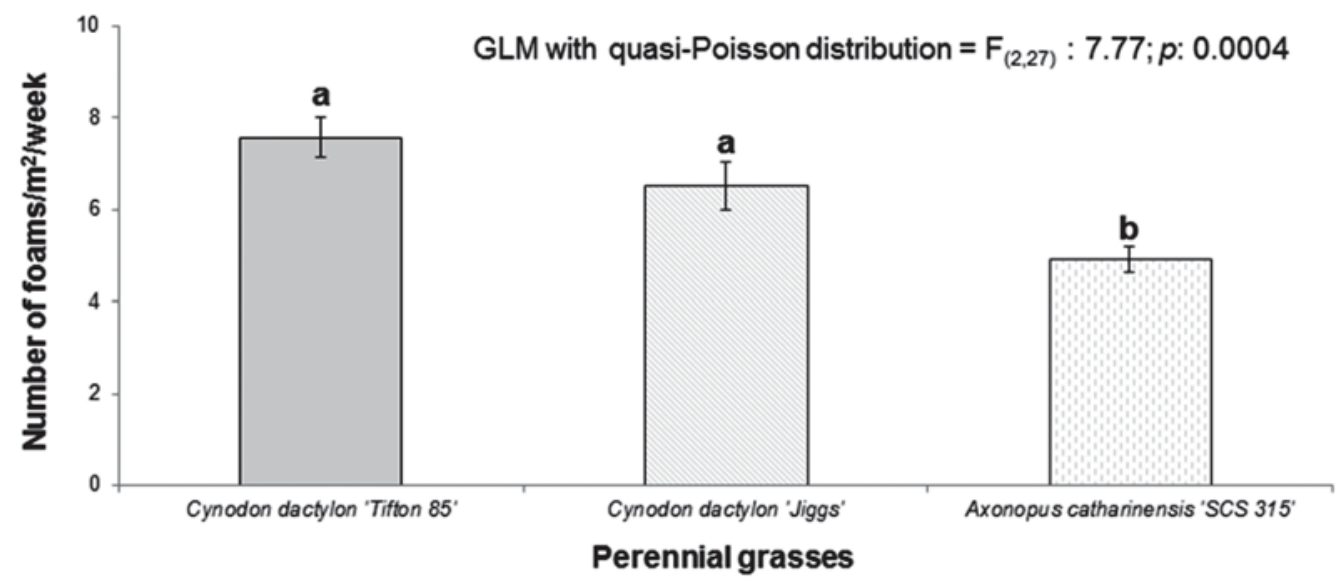

Figure 1 - Average incidence of spittlebug nymphs (foam) in three perennial grasses. Chapecó, SC, Brazil 2015-2016.



Figure 2 - Fluctuation of spittlebug nymphs (foam) in three perennial grasses. Note: Arrows indicate two mowing managements performed to remove herbage leftover. Chapecó, SC, Brazil - 2015/2016.

Furthermore, the last population peak of spittlebugs was delayed in the plot cultivated with A. catharinensis cv. SCS 315 Catarina Gigante, which can indicate a plant resistance of antibiosis type. In previous studies conducted in South Brazil (Lohmann et al., 2010; Chiaradia et al., 2013), three or four population peaks were verified during the critical period of spittlebugs' incidence.

In general, high population densities of spittlebugs are positively correlated to temperature, relative humidity and precipitation (Melo et al., 1984; Auad et al., 2009).
However, our results showed that the number spittlebug nymphs foam was not significant correlated with the climatic parameters occurred prior the assessment of spittlebug population (Table 1). Corroborating our results, Lohmann et al. (2010) verified that rainfall, temperature and pasture height had little correlation with the population dynamics of spittlebugs. However, Chiaradia et al. (2013) verified that the average monthly minimum temperature is directly related with spittlebugs population fluctuation $(r=0.63)$ while the total monthly rainfall that occurs in Western Santa Catarina has insignificant relation. 
Table 1 - Spearman's correlation coefficient (r) between the number of spittlebug nymphs (foam) in three perennial grasses (plots) and climatic parameters. Chapecó, SC, Brazil-2015/2016

\begin{tabular}{|c|c|c|c|c|c|c|}
\hline & $\begin{array}{l}\text { Number of } \\
\text { nymphs foam } \\
(\text { Plot A) }\end{array}$ & $\begin{array}{l}\text { Number of } \\
\text { nymphs foam } \\
(\text { Plot B })\end{array}$ & $\begin{array}{l}\text { Number of } \\
\text { nymphs foam } \\
(\text { Plot C) }\end{array}$ & $\begin{array}{l}\text { Average } \\
\text { temperature }\end{array}$ & Precipitation & $\begin{array}{l}\text { Relative } \\
\text { humidity }\end{array}$ \\
\hline $\begin{array}{l}\text { Number of nymphs } \\
\text { foam (Plot A) }\end{array}$ & 1.00 & $\begin{array}{c}\mathbf{0 . 5 6} \\
(\mathrm{P}=0.0004)\end{array}$ & $\begin{array}{c}\mathbf{0 . 8 7} \\
(\mathrm{P}<0.0001)\end{array}$ & $\begin{array}{c}0.18 \\
(\mathrm{P}=0.2880)\end{array}$ & $\begin{array}{c}0.15 \\
(\mathrm{P}=0.4027)\end{array}$ & $\begin{array}{c}0.18 \\
(p=0.3142)\end{array}$ \\
\hline $\begin{array}{l}\text { Number of nymphs } \\
\text { foam (Plot B) }\end{array}$ & $\begin{array}{c}\mathbf{0 . 5 6} \\
(\mathrm{P}=0.0004)\end{array}$ & 1.00 & $\begin{array}{c}\mathbf{0 . 5 0} \\
(\mathrm{P}=0.0020)\end{array}$ & $\begin{array}{c}0.13 \\
(\mathrm{P}=0.4472)\end{array}$ & $\begin{array}{c}0.22 \\
(\mathrm{P}=0.1985)\end{array}$ & $\begin{array}{c}0.31 \\
(p=0.0674)\end{array}$ \\
\hline $\begin{array}{l}\text { Number of nymphs } \\
\text { foam (Plot C) }\end{array}$ & $\begin{array}{c}\mathbf{0 . 8 7} \\
(\mathrm{P}<0.0001)\end{array}$ & $\begin{array}{c}\mathbf{0 . 5 0} \\
(\mathrm{P}=0.0020)\end{array}$ & 1.00 & $\begin{array}{c}0.33 \\
(\mathrm{P}=0.0558)\end{array}$ & $\begin{array}{c}0.06 \\
(\mathrm{P}=0.7443)\end{array}$ & $\begin{array}{c}0.10 \\
(p=0.5661)\end{array}$ \\
\hline Average temperature & $\begin{array}{c}0.18 \\
(\mathrm{P}=0.2880)\end{array}$ & $\begin{array}{c}0.13 \\
(\mathrm{P}=0.4472)\end{array}$ & $\begin{array}{c}0.33 \\
(\mathrm{P}=0.0558)\end{array}$ & 1.00 & $\begin{array}{c}\mathbf{- 0 . 4 9} \\
(\mathrm{P}=0.0030)\end{array}$ & $\begin{array}{c}-0.16 \\
(p=0.3536)\end{array}$ \\
\hline Precipitation & $\begin{array}{c}0.15 \\
(\mathrm{P}=0.4027)\end{array}$ & $\begin{array}{c}0.22 \\
(\mathrm{P}=0.1985)\end{array}$ & $\begin{array}{c}0.06 \\
(\mathrm{P}=0.7443)\end{array}$ & $\begin{array}{c}-0.49 \\
(\mathrm{P}=0.0030)\end{array}$ & 1.00 & $\begin{array}{c}\mathbf{0 . 5 5} \\
(p=0.0006)\end{array}$ \\
\hline Relative humidity & $\begin{array}{c}0.18 \\
(\mathrm{P}=0.3142)\end{array}$ & $\begin{array}{c}0.31 \\
(\mathrm{P}=0.0674)\end{array}$ & $\begin{array}{c}0.10 \\
(\mathrm{P}=0.5661)\end{array}$ & $\begin{array}{c}-0.16 \\
(\mathrm{P}=0.3536)\end{array}$ & $\begin{array}{c}\mathbf{0 . 5 5} \\
(\mathrm{P}=0.0006)\end{array}$ & 1.00 \\
\hline
\end{tabular}

Probably, the interaction of different climate parameters has a significant effect on spittlebugs dynamics, affecting their generation time (e.g.: temperature) and their survival rate (e.g.: humidity).

The experimental design used in this study was based on sampling of spittlebug nymphs foam using an iron square $(0.5 \times 0.5 \mathrm{~m})$, which is the appropriated practical method used by farmers for insect monitoring in pastures. Due to insect adult mobility between plots, we did not consider the adults dynamics. In this step, our objective was obtained more accurate and user-friendly information for pest control decisionmaking process. According to Valério (2009), the adequate moment for control method adoption is a key point for success of chemical or biological control strategies of spittlebugs. In light of this, the information generated in this study are useful to support integrated management strategies of spittlebugs in pastures and, consequently, reduce the impact of these insect pests on forage production, as well as the negative effects on productivity and costs of dairy farming developed in the region.

\section{ACKNOWLEDGMENTS}

We thank Zelinda Meneguzzi, Marcelo Rigo, and Leandro Zanchetta (Epagri/Cepaf) for technical assistance and Sônia Bortolanza and Clairton José Soldi (Epagri/Cetrec) for allowing us using his pasture plots. We also thank the "Conselho Nacional de Desenvolvimento Científico e Tecnológico" (CNPq,
Process number 445518/2014-6) and SR Rural Programm (Project 6611739) for financial support.

\section{LITERATURE CITED}

AGUIRRE, A.L.M.; CARDONA, C.; MILES, J.W.; SOTELO, G. Characterization of resistance to adult spittlebugs (Hemiptera: Cercopidae) in Brachiaria spp. Journal of Economic Entomology, v.10, n.4, p.1871-1877, 2013.

AUAD, A.M.; SIMÕES, A.D.; PEREIRA, A.V.; BRAGA, A.L.F. Seleção de genótipos de capimelefante quanto à resistência à cigarrinha-daspastagens. Pesquisa Agropecuária Brasileira, v.42, n.8, p.1077-1081, 2007.

AUAD, A.M.; CARVALHO, C.A.; SILVA, D.M.; DERESZ, F. Flutuação populacional de cigarrinhas-das-pastagens em braquiária e capimelefante. Pesquisa Agropecuária

Brasileira, v.44, p.1205-1208, 2009.

CHIARADIA, L.A.; MIRANDA, M.; FEDATTO, V.J. Flutuação populacional de cigarrinhas-daspastagens na grama-missioneira-gigante.

Agropecuária Catarinense, v.26, p.70-75, 2013.

CONGIO, G.F.S.; CORSI, M.; ALMEIDA, P.C.; GOULART, R.D.C.D.; PASSOS, L.P.; KOPP, M.M. Rebrota do capim-marandu submetido ao ataque de cigarrinhas. Arquivos do Instituto Biológico, v.79, p.389-396, 2012. 
FERNANDES, C.O.M. Princípios da produção de leite a pasto. In: CÓRDOVA, U.A. (Ed.), Produção de leite à base de pasto em Santa Catarina. Epagri, Florianópolis, 2012. p.15-30.

GRISOTO, E.; VENDRAMIM, J.D.; LOURENÇÃO, A.L.; USBERTI FILHO, J.A.; DIAS, C.T.S. Biologa de Mahanarva fimbriolata em gramíneas forrageiras. Ciência Rural, v.44, n.6, p.10431049, 2014.

HINDE, J.; DEMÉTRIO, C.G.B. Overdispersion: models and estimation. Computational Statistics and Data Analysis, v.27, p.151$170,1998$.

KORNDÖRFER, A.P.; GRISOTO, E.; VENDRAMIM, J.D. Induction of insect plant resistance to the spittlebug Mahanarva fimbriolata Stal (Hemiptera: Cercopidae) in sugarcane by silicon application. Neotropical Entomology, v.40, n.3, p.387-392, 2011.

LOHMANN, T.R.; PIETROWSKI, V.; BRESSAN, D.F. Flutuação populacional de cigarrinhas-daspastagens na região Oeste do Paraná. Semina, v.31, p.1291-1298, 2010.

NELDER, J.A.; WEDDERBURN, R.W.M. Generalized linear models. Journal of the Royal

Statistical Society, v.135, p.370-384, 1972.

PANDOLFO, C.M.; BRAGA, H.J.; SILVA JÚNIOR, V.P.; MASSIGNAM, A.M.; PEREIRA, E.S.; THOMÉ, V.M.R.; VALCI, F.V.A. Atlas Climatológico do Estado de Santa Catarina. Florianópolis: Epagri, 2002. 13 p.

PERON, A.J.; EVANGELISTA, A.R. Degradação de pastagens em regiões de cerrado. Ciência \& Agrotecnologia, v.28, n.3, p.655-661, 2004.

R DEVELOPMENT CORE TEAM. R: A language and environment for statistical computing. $R$ Foundation for Statistical Computing, Vienna, Austria, 2012.
RESENDE, T.T.; AUAD, A.M.; FONSECA, M.G.; SANTOS, T.H.; VIEIRA, T.M. Impact of the spittlebug Mahanarva spectabilis on signal grass. The Scientific World Journal, v.201, p.1-6, 2012.

RESENDE, T.T.; AUAD, A.M.; FONSECA, M.G.; SOBRINHO, F.S.; SANTOS, D.R.; SILVA, S.E.B.

The damage capacity of Mahanarva spectabilis (Distant, 1909) (Hemiptera: Cercopidae) adults on Brachiaria ruziziensis pasture. The Scientific World Journal, v.201, p.1-6, 2013.

SÍNTESE ANUAL DAAGRICULTURA DE SANTA CATARINA 2014-2015. Florianópolis: Epagri/Cepa, 2014. http://www.epagri.sc.gov.br/. Accessed 03 August 2017.

SOBRINHO, F.S.; AUAD, A.M.; SILVA, L.; FRANCISCO, J. Genetic variability in Brachiaria ruziziensis for resistance to spittlebugs. Crop Breeding \& Applied Biotechnology, v.10, n. 1, p.83-88, 2010.

SOLOS DO ESTADO DE SANTA CATARINA. Rio de Janeiro: Embrapa Solos, 2004. 713p. (Embrapa Solos. Boletim de pesquisa e desenvolvimento, 46).

VALÉRIO, J.R. Cigarrinhas-das-pastagens. Campo Grande, MS: Embrapa gado de Corte, 2009. 51 p. (Documentos/Embrapa Gado de corte, 179).

VALÉRIO, J.R.; NAKANO, O. Danos causados pelo adulto da cigarrinha Zulia entreriana na produção e qualidade de Brachiaria decumbens. Pesquisa Agropecuária Brasileira, v.23 n.5, p.447-453, 1988.

VALÉRIO, J.R.; NAKANO, O. Danos causados pelo adulto da cigarrinha-das-pastagens Zulia entreriana (Berg., 1879) (Homoptera: Cercopidae) em plantas de Brachiaria decumbens Stapf., mantidas em diferentes níveis de umidade. Anais da Sociedade Entomológica do Brasil, v.16, n.2, p.341-350, 1987.

Recebido para publicação em 03/06/2018 e aprovado em 11/12/2018. 